\title{
ASPEK HUKUM PERATURAN DAN KEBIJAKAN PEMERINTAH INDONESIA MENGHADAPI LIBERALISASI EKONOMI REGIONAL: MASYARAKAT EKONOMI ASEAN 2015
}

(Legal aspect of Indonesian Government Regulation against Regional Economic Liberalization: ASEAN Economic Community 2015)

\author{
Masnur Tiurmaida Malau \\ Pusat Penelitian dan Pengembangan Sistem Hukum Nasional BPHN \\ Email: moniquest_7th@yahoo.com/moniq.malau@gmail.com
}

Naskah diterima: 17 Juli 2014; revisi: 12 September 2014; disetujui: 15 September 2014

\begin{abstract}
Abstrak
Akselerasi penerapan Masyarakat Ekonomi ASEAN di 2015 menuntut upaya-upaya persiapan yang maksimal dari negaranegara anggotanya termasuk Indonesia. Salah satu sendi kehidupan yang penting dipersiapkan yaitu sendi hukum dalam sektor tertentu seperti persaingan usaha dan liberalisasi jasa. Hal ini penting karena dapat menciptakan alur serta panduan bagi suatu negara untuk mencapai tujuan yang diharapkan dan juga dapat mengarahkan masyarakat serta perangkat negara lainnya menuju tahap yang ingin dicapai, sehingga pengaturan melalui kebijakan (policy) ini merupakan langkah pertama sebagai upaya mempersiapkan Indonesia menghadapi Masyarakat Ekonomi ASEAN yang akan datang. Kajian ini dilakukan dengan tujuan untuk memberikan pandangan bagaimana kesiapan Indonesia dalam hal peraturan untuk menghadapi liberalisasi jasa dan persaingan usaha. Metode pendekatan yang digunakan dalam kajian ini adalah deskriptif analitis yang menjelaskan dan menganalisis dari sisi hukum berbagai peraturan yang dilakukan oleh pemerintah Indonesia dalam persiapan menuju ASEAN Economic Community 2015. Hasil dari kajian ini menunjukkan bahwa pemerintah Indonesia berusaha mempersiapkan diri melalui berbagai peraturanguna menyongsong ASEAN Economic Community 2015 walaupun dari segi pelaksanaan belum optimal dan belum menyentuh seluruh segi kehidupan bernegara, pemerintah Indonesia harus segera mengoptimalkan usaha guna memperkuat kesiapan Indonesia bersaing dalam ASEAN Economic Community 2015.

Kata Kunci: kebijakan, perangkat negara, persaingan usaha
\end{abstract}

\begin{abstract}
:
Towards ASEAN Economic Community 2015 ASEAN member countries including Indonesia need to maximize efforts in preparing. One of the important parts of life which need to prepare is law aspect by some legal instruments in specific aspect such as competition and service liberalization. This is important because legal instruments can create pattern and guidelines for a country to achieve aims and to guide their society and government to achieve path of life that they want, so policy recognize as starting step for countries among ASEAN to move forward towards ASEAN Economic Community. This research doing to give perspective of how Indonesia government's preparation in regulation towards service liberalization and competition. Approaching methods that using in this research is analyzing descriptive that describe and analyzing what policies that government had taken and how to implement that policies to meet ASEAN Economic Community. Result of this research shows that Indonesian government has done many efforts through some policies towards ASEAN Economic Community 2015 eventough from implementation perspective cannot reach all society's aspect of life in order to reach that goal Indonesian government should optimize policies to strengthening Indonesia's competitiveness towards ASEAN Economic Community 2015.
\end{abstract}

Keywords: policy, legal instrument, competition 


\section{A. Pendahuluan}

Disepakatinya Visi ASEAN 2020 pada bulan Desember 1997 di Kuala Lumpur menandai sebuah babak baru dalam sejarah integrasi ekonomi di kawasan Asia Tenggara. Dalam deklarasi tersebut, pemimpin negara-negara ASEAN sepakat untuk mentransformasikan kawasan Asia Tenggara menjadi sebuah kawasan yang stabil, sejahtera dan kompetitif, didukung oleh pembangunan ekonomi yang seimbang, pengurangan angka kemiskinan dan kesenjangan sosio-ekonomi di antara negara-negara anggotanya. ${ }^{1}$ Komitmen untuk menciptakan suatu Masyarakat ASEAN (ASEAN Community) sebagaimana dideklarasikan dalam visi tersebut, kemudian semakin dikukuhkan melalui ASEAN Concord II pada Pertemuan Puncak di Bali Oktober 2003, atau yang lebih dikenal sebagai Bali Concord II, dimana para pemimpin ASEAN mendeklarasikan pembentukan Masyarakat Ekonomi ASEAN (ASEAN Economic Community) sebagai tujuan dari integrasi ekonomi kawasan pada $2020 .^{2}$

Dalam Pertemuan Tingkat Menteri ASEAN (ASEAN Economic Ministers Meeting-AEM) yang diselenggarakan pada bulan Agustus 2006 di Kuala Lumpur, komitmen yang kuat menuju terbentuknya integrasi ekonomi kawasan ini diejawantahkan ke dalam gagasan pengembangan sebuah cetak biru menuju Masyarakat Ekonomi ASEAN yang kemudian secara terperinci disahkan dan diadopsi oleh seluruh negara anggota ASEAN pada November 2007. Bahkan, sebelumnya dalam Pertemuan Puncak ASEAN ke-12 pada Januari 2007, komitmen yang kuat para pemimpin negaranegara ASEAN terhadap pembentukan MEA ini, semakin tercermin dari disepakatinya upaya percepatan terwujudnya komunitas tersebut pada tahun 2015. Pada pertemuan tersebut, para pemimpin ASEAN sepakat untuk mempercepat pembentukan MEA pada tahun 2015 dan mentransformasikan ASEAN menjadi sebuah kawasan dimana barang, jasa, investasi, pekerja terampil, dan arus modal dapat bergerak dengan bebas.

AEC tahun 2015 merupakan suatu program bagi negara-negara ASEAN untuk lebih meningkatkan kualitas ekonomi khususnya perdagangan sebagaimana terdapat dalam ASEAN Economic Community (AEC) Blueprint. ${ }^{3}$ AEC Blueprint sebagai arahan atau acuan perwujudan AEC 2015 yang akan datang. Dalam AEC Blueprint terdapat beberapa pilar, namun dalam kajian ini fokus penulis terletak pada pilar Association of South East Asia Nations (ASEAN) sebagai pasar tunggal dan berbasis produksi tunggal yang didukung dengan unsur aliran bebas barang, jasa, investasi, tenaga kerja terdidik, dan aliran modal yang lebih bebas dan terintegrasi dalam satu kawasan di regional Asia Tenggara.ASEAN Community dibentuk dengan tujuan untuk lebih mempererat integrasi ASEAN dalam menghadapi perkembangan konstelasi internasional baik dalam bidang ideologi, politik, ekonomi, sosial budaya, maupun keamanan dan pertahanan.

AEC yang telah disepakati pada Konferensi Tingkat Tinggi (KTT) ASEAN ke-19 yang diselenggarakan di Bali, 17 November 2011

ASEAN Vision 2020, http://www.aseansec.org/1814. htm, (diakses 8 September 2014).

ASEAN Concord II/Bali Concord II, http://www.aseansec.org/15159.htm, (diakses 8 September 2014).

ASEAN Economic Community Blueprint,http://www.aseansec.org/21083.pdf, (diakses 8 September 2014). 
ini telah merumuskan kesepakatan bersama para pemimpin negara-negara ASEAN berupa pencapaian ASEAN Community yang dimulai dengan penerapan AEC pada 2015. Pada 2015 nanti, ASEAN akan terintegrasi menjadi satu masyarakat ekonomi yang tergabung dalam ASEAN Economic Community (AEC) atau disebut juga "Masyarakat Ekonomi ASEAN".

Area kerjasama AEC meliputi pengembangan sumber daya manusia dan peningkatan kapasitas, pengakuan kualifikasi profesional, konsultasi lebih dekat pada kebijakan makro ekonomi dan keuangan, langkah-langkah pembiayaan perdagangan, peningkatan infrastruktur dan konektivitas komunikasi, pengembangan transaksi elektronik melalui e-ASEAN, mengintegrasikan industri di seluruh wilayah untuk mempromosikan sumber daya daerah, dan meningkatkan keterlibatan sektor swasta untuk membangun AEC. ${ }^{4}$

Dalam rangka mendukung pembentukan MEA negara-negara anggota telah menyepakati pembentukan ASEANFree TradeArea(AFTA)yang dimulai dengan komitmen untuk menurunkan tariff barrier hingga mencapai kisaran 0 (nol) hingga 5 persen. Untuk mencapai komitmen Pasar Tunggal ASEAN 2015, kondisi tersebut akan ditingkatkan lagi dengan upaya untuk menghilangkan tariff (hingga nol persen) dan non tariff barrier dalam kegiatan perdagangan intrakawasan. ${ }^{5}$ Pasar Tunggal ASEAN tidak hanya mengacu pada konsep ASEAN sebagai single market, tetapi juga sebagai single production base yang akan membutuhkan liberalisasi capital dan tenaga kerja terampil. ${ }^{6}$

Dampak lain pemberlakuan MEA yakni MEA menjadi lisensi persaingan (license to competition) antara mereka di dalam kawasan. Kebijakan ini diambil dalam rangka terjadinya persaingan di tingkat global. Dalam rangka mendorong lahirnya kawasan yang memiliki daya saing, ASEAN sudah menyiapkan kerangka bagaimana mekanisme pasar bebas ASEAN dirancang. Rumusan kebijakan persaingan menjadi isu yang sangat strategis. Salah satu karakteristik kunci MEA adalah tercapainya Competitive Economic Region. Namun apakah semua negara-negara ASEAN memiliki kemampuan yang sama untuk bersaing meski dengan tetangga sendiri, melalui implementasi kebijakan dan hukum persaingan usaha. Dalam konteks pasar bebas ASEAN, Kebijakan dan Hukum Persaingan Usaha ini akan sangat dibutuhkan karena pada tahun 2015 nanti pasar dimana transaksi perdagangan barang dan atau jasa sudah terbuka.

\footnotetext{
Mohamed Jahwar Hassan, The Resurgence of China and India, major Power Rivalry and The Response of ASEAN, dalam Hadi Soesastro dan Clara Joewono (eds.), The Inklusif Regionalist, , (Jakarta: Centre For Strategic And International Studies Indonesia, 2007), hlm. 139.

5 Hambatan non tarif terdiri dari hambatan kebijakan impor, persyaratan standarisasi, pengujian, labeling dan sertifikasi, tindakan anti dumping dan pencegahan, subsidi ekspor dan dukungan domestik, pengadaan oleh pemerintah, hambatan jasa, kurangnya perlindungan hukum terhadap Hak Kekayaan Intelektual dan hambatanhambatan lainnya. Hambatan kebijakan impor, sebagai contoh disesuaikan dengan pasal XX dari GATT yang memperbolehkan larangan impor atas dasar kesehatan moral publik, keselamatan manusia, binatang atau tanaman setempat, atau jika menyangkut harta nasional yang bersifat artistik, histori ataupun arkeologis dalam Ariawan Gunadi dan Serian Wijatno, Perdagangan Bebas dalam Perspektif Hukum Perdagangan Internasional (Jakarta: PT. Grasindo, 2014), hlm. 39.

6 Zainuddin Djafar, Moon Young Ju dan Anissa Farha Mariana, Peran Strategis Indonesia dalam Pembentukan ASEAN dan Dinamikanya, Kajian Kebijakan Polugri RI, UKM Regional, Implikasi Liberalisasi Perdagangan, Realitas Piagam ASEAN dan Esensi Kompetisi Regional, (Jakarta: Penerbit Universitas Indonesia (UI Press), 2012), hlm. 132.
} 
Di tahun 2015, transaksi perdagangan dan jasa akan menyatu dan berintegrasi dalam satu pasar bersama. Hal ini berarti bahwa pelaku usaha di Indonesia khususnya pelaku usaha yang berkeinginan untuk melakukan ekspansi usaha di ASEAN atau berhubungan dengan pelaku usaha di negara-negara ASEAN lainnya harus memahami hukum usaha yang berlaku di negara-negara anggota termasuk hukum persaingan usaha. Usaha untuk menciptakan daya saing melalui hukum dan kebijakan persaingan, ASEAN melalui Sekretariat ASEAN telah melakukan sejumlah aksi. Melalui ASEAN Expert Group on Competition (AEGC) sebagai lembaga struktural di ASEAN yang menangani implementasi hukum persaingan telah menginisiasi dan mempromosikan hal ini. Tercatat hingga saat ini, lima negara ASEAN yang telah memberlakukan hukum persaingan yaitu Indonesia dan Thailand (1999), Singapore dan Vietnam (2004) serta Malaysia (2012), sementara 5 negara lainnya masih dalam tahap legislasi. ${ }^{7}$

Setelah gelombang krisis ekonomi melanda sebagian Asia Timur dan Tenggara pada akhir 1990-an, muncul perhitungan dan analisis yang lebih responsif terhadap kemungkinan dampak negatif liberalisasi ekonomi. Kejadian tersebut telah memperkuat legitimasi aktoraktor ekonomi alternatif yang lebih stabil dan "tahan banting" yang selama ini belum diperhitungkan secara teoritis dalam paradigma ilmu hubungan internasional, yaitu sektor UKM.
Tren pengembangan UKM di ASEAN, seperti halnya integrasi ekonomi ASEAN tidak terlepas dari pengaruh China Factor yang kemudian diadopsi juga oleh Korea Selatan. ${ }^{8}$

Pentingnya pertumbuhan dan pengembangan sektor UKM skala regional juga perlu diperhitungkan, terutama dalam rangka integrasi ekonomi ASEAN. Wacana peningkatan daya saing UKM regional ini juga dipicu oleh gelombang krisis Asia 1997 yang membuktikan bahwa sektor UKM lebih stabil dibandingkan dengan kalangan korporasi. Peran UKM regional dalam pertumbuhan ekonomi ASEAN baru mulai marak dibicarakan setelah tahun 2003 sejak dicetuskannya rencana penerapan AEC. Peran sektor UKM sebagai backbone perekonomian negara-negara anggota ASEAN semakin diakui. Disamping sebagai penyedia lapangan kerja domestik terbesar, sektor UKM juga dipandang sebagai kontributor utama bagi pertumbuhan ekonomi. Sektor UKM yang lebih kompetitif dan inovatif akan membantu terlaksananya pembangunan yang berkelanjutan di kawasan ASEAN, terutama sebagai pendorong kesuksesan AEC.

Berdasarkan data dari Divisi Populasi Perserikatan Bangsa-bangsa (PBB) jumlah populasi penduduk di negara ASEAN mencapai 633,1 juta jiwa di tahun 2015 nanti dengan populasi Indonesia mencapai 237,641,326 jiwa $^{9}$ hingga tahun 2010 saja sehingga Indonesia menjadi negara dengan jumlah penduduk terbanyak di kawasan regional ASEAN, hal 
ini dapat menjadi peluang sekaligus menjadi tantangan bagi Indonesia dalam menghadapi pasar tunggal ASEAN 2015, maka Pemerintah Indonesia dituntut menghasilkan berbagai Peraturan dan Kebijakan yang tepat agar tujuan ASEAN dan Tujuan Nasional dapat tercapai secara beriringan.

Sebagai salah satu pendiri ASEAN sudah seharusnya pemerintah Indonesia melakukan berbagai upaya guna meningkatkan kinerja lembaga-lembaga pemerintahan dan non pemerintahan yang sudah ada dalam menghadapi integrasi perekonomian melalui MEA. ${ }^{10}$ Sektor Usaha Kecil Menengah (UKM) mendapat perhatian dalam upaya meningkatkan daya saing ekonomi Indonesia dalam MEA mengingat bahwa krisis moneter yang pernah terjadi di dunia telah membuktikan bahwa krisis keuangan tidak berimbas besar pada sektor UKM Indonesia sehingga sudah sepantasnya UKM mendapat porsi yang lebih besar untuk ditingkatkan dan dikembangkan sehingga layak bersaing dalam kompetisi ekonomi Internasional pada umumnya dan regional khususnya.

Dari tahun ke tahun peran UKM Indonesia terhadap perolehan PDB Nasional cenderung stagnan, dalam perolehan PDB Nasional kelompok usaha kecil memberikan kontribusi yang lebih besar dibandingkan dengan kelompok usaha menengah. Institusi pemerintahan yang berwenang dalam perumusan kebijakan UKM di Indonesia adalah Kementerian Koperasi dan Usaha Kecil dan Menengah. ${ }^{11}$ Secara umum pengembangan sektor UKM di Indonesia tidak terpisahkan dari koperasi. Pemerintah membentuk Kementerian Negara Koperasi dan UKM untuk membantu Presiden dalam merumuskan kebijakan di bidang koperasi dan UKM. Dalam melaksanakan tugasnya, Kementerian Negara KUKM memiliki fungsifungsi berikut: (1) perumusan kebijakan nasional di bidang UKM; (2) koordinasi pelaksanaan kebijakan;(3) pengelolaan kekayaan negara yang menjadi tanggung jawab Kementerian Koperasi;(4) pengawasan atas pelaksanaan tugas; dan (5) penyampaian laporan, saran, dan pertimbangan kepada Presiden.

Dalam menghadapi MEA banyak tantangan yang dihadapi sektor UKM Indonesia. Mitsuhiro Hayashi dalam hasil penelitiannya telah menyatakan bahwa permasalahan dalam pengembangan UKM di Indonesia adalah belum adanya proses implementasi yang selaras dengan kebijakan pemerintah. Hampir senada dengan pendapat tersebut, Thomas A.Timberg menyatakan bahwa hambatan pengembangan UKM di Indonesia justru disebabkan oleh sistem birokrasi dan situasi ekonomi-politik dalam negeri yang kurang kondusif. ${ }^{12}$

Beberapa Kementerian telah melakukan persiapan melalui kebijakan-kebijakannya antara lain empat prioritas kebijakan Kementerian Perdagangan khususnya Direktorat Kerjasama ASEAN yang menekankan UKM sebagai salah satu sektor yang dianggap dapat menjadi penggerak perekonomian yang setara di kawasan ASEAN. Empat kebijakan prioritas yang terkait UKM yaitu mempercepat

\footnotetext{
10 Dodi Mantra, Hegemoni dan diskursus Neoliberalisme: Menelusuri Langkah Indonesia Menuju Masyarakat Ekonomi ASEAN 2015 (Bekasi: Mantra Press, 2011) hlm. 97.

11 M. Kuncoro, Analisis Spasial dan Regional: Studi Aglomerasi dan Kluster Industri Indonesia. (Yogyakarta: UPP AMP YKPN, 2002) hlm. 51.

12 Hayashi, Mitsuhiro, "Development of SMEs in the Indonesian Economy", Journal of Asian Economics (2002) : 9.
} 
pengembangan UKM, memperkuat daya saing dan dinamika UKM ASEAN dengan memfasilitasi akses terhadap informasi, pasar, sumber daya manusia dan keahlian, keuangan dan teknologi, memperkuat UKM ASEAN untuk membantu masalah-masalah makro ekonomi, kesulitan keuangan maupun tantangan dalam liberalisasi perdagangan serta meningkatkan kontribusi UKM bagi pertumbuhan ekonomi menyeluruh dan pengembangan ASEAN sebagai kawasan. ${ }^{13}$

Upaya penguatan kinerja bukan hanya tugas dari Kementerian terkait seperti Kementerian Perdagangan serta Kementerian lainnya di bidang perekonomian saja, melainkan seluruh Kementerian atau lembaga selaku perangkat negara pun harus turut serta meningkatkan kinerja sebagai upaya meningkatkan daya saing untuk menghadapi Masyarakat Ekonomi ASEAN 2015 yang akan datang, karena pemberlakuan AEC 2015 akan berdampak sangat luas terhadap segi kehidupan bernegara. Pemerintah selaku perangkat negara yang diberikan kewenangan untuk melakukan pengaturan melalui kebijakan harus dapat mengoptimalkan peran dan fungsinya, karena peluang besar yang terdapat dalam pemberlakuan AEC 2015 dapat menjadi pedang bermata dua jika tidak dipersiapkan dengan baik.

Pemberlakuan AEC 2015 akan berdampak luas terhadap sendi-sendi kehidupan berbangsa sehingga sudah seharusnya membuat pemerintah Indonesia berpikir lebih keras karena terintegrasinya perekonomian seantero Asia
Tenggara ini akan benar-benar memperluas potensi masing-masing negara. ${ }^{14}$ Model ini berhasil diterapkan sebelumnya di Eropa melalui Uni Eropa. Akankah Indonesia berhasil mencapai tujuan AEC sekaligus meningkatkan pertahanan nasional dan melindungi kepentingan Nasional atau AEC justru menjadi ancaman bagi Indonesia.

Berbagai pendapat atau kritikan terkait ketidaksiapan Indonesia dalam menghadapi AEC patut dipertimbangkan. Kondisi ini tentu bukanlah hal yang baik bagi Indonesia karena hal ini dapat mempengaruhi pandangan negaranegara lain terhadap Indonesia. ${ }^{15}$ Kekhawatiran serta stigma yang terdapat di masyarakat baik nasional maupun internasional harus disikapi dan ditangani dengan hati-hati oleh pemerintah karena seluruh upaya yang ditempuh maupun yang akan ditempuh harus sesuai tujuan agar menghilangkan atau meminimalisir anggapan pesimis tersebut, karena sedikit kekeliruan dapat menjadi ancaman bagi Indonesia dipenghujung tahun 2015 nanti.

Dari uraian latar belakang diatas dan dalam rangka menjawab pertanyaan atau keraguan yang diuraikan tersebut, penulis memfokuskan untuk menjawab Bagaimana aspek hukum Persaingan Usaha menghadapi MEA 2015?, dan Bagaimana peluang dan tantangan bagi Indonesia dalam menyongsong ASEAN Economic Community (AEC) 2015?, serta Peraturan dan kebijakan apa saja yang diambil Pemerintah 
Indonesia menyongsong ASEAN Economic Community 2015?

\section{B. Metode Penelitian}

Penelitian ini menggunakan metode penelitian hukum yuridis normatif ${ }^{16}$. Data yang ada dihubungkan satu sama lain melalui studi kepustakaan (library research), dikaji dan diinterpretasi dan dianalisa untuk selanjutnya ditarik kesimpulannya. Metode penelitian yuridis normatif adalah penelitian yang mengacu kepada norma-norma hukum yang terdapat dalam peraturan perundang-undangan, konvensi internasional, perjanjian internasional dan putusan-putusan pengadilan ${ }^{17}$. Dimana sumber datanya diperoleh dari bahan kepustakaan atau data sekunder, ${ }^{18}$ yang terdiri dari dari bahan hukum primer, antara lain norma atau kaidah dasar, yaitu pembukaan UUD NRI Tahun 1945, Batang Tubuh UUD NRI 1945, dan peraturan perundang-undangan sedangkan bahan hukum sekunder, antara lain buku-buku, hasil penelitian, serta pendapat pakar hukum. Data yang diperoleh akan dianalisis dengan metode deskriptif kualitatif.

\section{Pembahasan}

\section{Aspek Hukum Persaingan Usaha Indonesia Menghadapi MEA 2015}

Indonesia sebagai salah satu negara pertama yang memberlakukan hukum persaingan te- lah berperan secara aktif menjadi centre of excellence dalam pengembangan hukum persaingan ini di ASEAN melalui pembagian pengalaman (sharing experience), pengiriman tenaga ahli ke negara anggota, tujuan studi banding dan tempat magang serta berkontribusi penting dalam penyusunan beberapa produk AEGC yaitu sebagai ketua dalam penyusunan Guidelines on Developing Core Competencies in Competition Policy and Law for ASEAN (2013) dan berkontribusi aktif dalam penyusunan ASEAN Regional Guidelines on Competition Policy (2010) dan Handbook on Competition Policy and Law in ASEAN for Business (2011) ${ }^{19}$. Implementasi ASEAN Economic Blueprint dalam mewujudkan MEA akan membawa konsekuensi baru bagi dunia usaha di Indonesia. Dalam perspektif kompetisi, konsekuensi dari terbukanya pasar akibat kebebasan peredaran barang dan jasa (free flow of goods and services) adalah munculnya persaingan baru, pasar bersangkutan baru dan potensi ketersentuhan pelaku usaha Indonesia dengan hukum persaingan negara-negara tetangga seperti Malaysia dan Singapura. ${ }^{20}$

Lalu bagaimana kesiapan Indonesia menghadapi MEA? Banyak kalangan yang khawatir kalau Indonesia malah jadi pecundang di era ini. MEA 2015 bisa saja menjadi berkah bagi Indonesia namun sekaligus menjadi petaka. MEA bisa menjadi petaka apabila produk pertanian kita tidak mampu bersaing

16 Soerjono Soekanto dan Sri Mamuji, Penelitian Hukum Normatif, Suatu Tinjauan Singkat (Jakarta: CV Rajawali, 1990), hlm. 15.

17 C.F.G Sunaryati Hartono, Penelitian Hukum di Indonesia Pada Akhir Abad ke-20 (Bandung: Alumni, 1994), hlm. 143.

18 Amiruddin dan Zainal Asikin, Pengantar Metode Penelitian Hukum, (Jakarta: Rajawali Pers, 2012), hlm. 118.

19 J. Bhagwati, The World Trading System at Risk, (Hertfordshire: Harvester Wheatsheaf, 1991) hlm. 77.

20 Shoffwan Al Banna Choiruzzad, Sedia Payung Sebelum Hujan: Perdagangan Bebas dampak bagi Para Pekerja dan Bagaimana Menghadapinya dalam Ariawan, Op cit., hlm. 175. 
dengan produk pertanian dari negara ASEAN yang lain. Aliran modal dan investasi dari luar hanya mengeruk hasil bumi dan tenaga kerja terdidik menjadi penonton di negaranya sendiri. Untuk itu perlunya upaya mengoptimalisasi sektor pertanian Indonesia di MEA 2015 dengan cara memperkokoh konektivitas antar wilayah untuk menjadi bagian di tingkat ASEAN, dan selanjutnya di tingkat global. Memberi ruang bagi setiap daerah untuk berkembang sesuai dengan keunikan dan comparative advantage yang dimilikinya, pengembangan inovasi teknologi dan penyiapan infrastruktur pendukung dalam rangka meningkatkan daya saing, harmonisasi prosedur, peraturan, dan standar yang menuju pada peningkatan kualitas dan keamanan pangan (mengacu pada AEC Blueprint), memasyarakatkan MEA sampai ke tingkat grass-root society. ${ }^{21}$

Kekhawatiran tidak hanya datang dari kalangan akademisi. Kalangan pelaku bisnis juga memiliki kekhawatiran yang sama tentang kesiapan Indonesia menghadapi pasar bebas ASEAN. Pemerintah maupun dunia usaha dianggap belum terlihat berupaya mengintegrasikan program untuk persiapan ke arah MEA. Padahal dalam menghadapi MEA, ada keterlibatan integratif dalam pembuatan kebijakan. Langkah ini sudah dilakukan negaranegara ASEAN lain seperti Singapura, Malaysia, dan Thailand. ${ }^{22}$ Sementara Indonesia masih harus berbenah. Mengapa? karena sektor swasta masih jauh berada di luar lingkaran pengambilan keputusan oleh negara. Indonesia diminta agar lebih sigap dalam melihat peluang dan tantangan menghadapi liberalisasi ekonomi Asia Tenggara. Pemerintah juga harus mendorong penciptaan pasar-pasar baru bagi berbagai produk Indonesia. Apabila Indonesia tidak siap, maka bisa dipastikan Indonesia hanya akan menjadi pasar berbagai produk impor. Semakin banyak kalangan yang menyangsikan kalau ekonomi Indonesia akan mampu menghadapi pasar bebas untuk kawasan ASEAN. Dasarnya, daya saing produk dalam negeri Indonesia masih lemah. ${ }^{23}$ Indikasinya dilihat dari banyaknya produk impor di pasar domestik. Ketahanan ekonomi menjelang pasar bebas ASEAN cukup mengkhawatirkan karena dengan daya saing kita yang terus merosot, yang dibuktikan dengan membanjirnya produkproduk impor, membanjirnya produk impor di pasar domestik menunjukkan daya saing produk domestik lemah, daya saing yang melemah harus dicermati, kalau tidak Indonesia akan menjadi bangsa yang kalah di Asia Tenggara.

\section{Peluang dan Tantangan Menuju Masyarakat Ekonomi ASEAN 2015.}

Indonesia merupakan negara yang terbesar populasinya di kawasan ASEAN. Masyarakat Indonesia juga merupakan negara heterogen dengan berbagai jenis suku, bahasa dan adat istiadat yang terhampar dari Sabang sampai Merauke. Indonesia mempunyai kekuatan ekonomi yang cukup bagus, pertumbuhan 
ekonomi tertinggi di dunia (4,5\%) setelah Republik Rakyat Tiongkok (RRT) dan India. Ini akan menjadi modal yang penting untuk mempersiapkan masyarakat Indonesia menuju AEC tahun 2015. ${ }^{24}$

Sebagai salah satu dari tiga pilar utama ASEAN Community 2015, AEC yang dibentuk dengan misi menjadikan perekonomian di ASEAN menjadi lebih baik serta mampu bersaing dengan Negara-negara yang perekonomiannya lebih maju dibandingkan dengan kondisi Negara-negara anggota ASEAN saat ini. ${ }^{25}$ Selain itu juga dengan terwujudnya ASEAN Community yang dimana didalamnya terdapat AEC, dapat menjadikan posisi ASEAN menjadi lebih strategis di kancah Internasional, bangsa Indonesia mengharapkan dengan terwujudnya komunitas masyarakat ekonomi ASEAN ini dapat membuka mata semua pihak, sehingga terjadi suatu dialog antar sektor yang dimana nantinya juga saling melengkapi diantara para stakeholder sektor ekonomi di Negara-negara anggota ASEAN ini sangat penting. ${ }^{26}$ Untuk itu kita harus mampu meningkatkan kepercayaan diri bahwa sebetulnya apabila kita memiliki kekuatan untuk bisa bangkit dan terus menjaga kesinambungan stabilitas ekonomi kita yang sejak awal pemerintahan Presiden Susilo Bambang Yudhoyono ini terus meningkat, angka kemiskinan dapat ditekan seminim mungkin, dan progres dalam bidang ekonomi lainnya pun mengalami kemajuan yang cukup signifikan.
Dengan hal tersebut banyak sekali yang bisa kita wujudkan terutama dengan merealisasikan AEC 2015 nanti.

Stabilitas ekonomi Indonesia yang kondusif ini merupakan sebuah peluang dimana Indonesia akan menjadi sebuah kekuatan tersendiri, apalagi dengan sumber daya alam yang begitu besar, maka akan sangat tidak masuk akal apabila kita tidak bisa berbuat sesuatu dengan hal tersebut. Peluang yang sudah terbuka ini, kalau tidak segera dimanfaatkan, kita akan tertinggal, karena proses ini juga diikuti gerak negara lain dan hal itu terus bergulir.

Secara garis besar peluang Indonesia menyongsong MEA seperti dibawah ini

a. Pasar Potensial Dunia.

Indonesia penduduk yang terbesar di kawasan (40\% dari total penduduk ASEAN). Hal ini dapat menjadikan Indonesia sebagai Negara ekonomi yang produktif dan dinamis yang dapat memimpin pasar ASEAN di masa depan dengan kesempatan penguasaan pasar dan investasi. Merupakan pasar potensial yang memiliki luas wilayah dan jumlah.

b. Negara tujuan investasi.

Indonesia merupakan Negara tujuan investor ASEAN. Proporsi investasi Negara ASEAN di Indonesia mencapai $43 \%$ atau hamper tiga kali lebih tinggi dari rata-rata proporsi investasi negara-negara ASEAN di ASEAN yang hanya sebesar $15 \% .^{27}$

24 Sjamsul Arifin, Dian Ediana Rae, Charles P.R. Joseph, Kerjasama Perdagangan Internasional: Peluang dan tantangan bagi Indonesia, (Jakarta: Elex Media Komputindo, 2007) hlm. 73.

25 The ASEAN Economic Community (AEC) shall be the goal of regional economic integration by 2015, AEC envisages the following key characteristics: (a) a single market and production base (b) a highly economic competitive region, (c) a region of equitable economic development, integrated into the global economy (http://www.aseansec. org/18757.htm diakses tanggal 10 September 2014).

26 Hendra Halwani, Ekonomi Internasional dan Globalisasi Ekonomi, (Jakarta: Ghalia Indonesia, 2002), hlm. 246.

27 Berry, A, E. Rodriguez and H. Sandee, "Small and Medium Enterprise Dynamics in Indonesia", (Bulletin of Indonesian Economic Studies, Vol. 37 No. 2, 2001):19. 
c. Peluang sebagai Negara pengekspor.

Indonesia berpeluang sebagai negara pengekspor, dimana nilai ekspor Indonesia ke intra-ASEAN hanya $18-19 \%$ sedangkan ke luar ASEAN berkisar $80-82 \%$ dari total ekspornya. Hal ini berarti peluang untuk meningkatkan ekspor ke intra-ASEAN masih harus ditingkatkan agar laju peningkatan ekspor ke intra-ASEAN berimbang dengan laju peningkatan dari intra-ASEAN. ${ }^{28}$

d. Liberalisasi Perdagangan barang ASEAN ${ }^{29}$ Liberalisasi perdagangan barang ASEAN akan menjamin kelancaran arus barang untuk pasokan bahan baku maupun bahan jadi di kawasan ASEAN karena hambatan tarif dan non tarif sudah tidak ada lagi. Kondisi pasar yang sudah bebas di kawasan dengan sendirinya akan mendorong pihak produsen dan pelaku usaha lainnya untuk memproduksi dan mendistribusikan barang yang berkualitas secara efisien sehingga mampu bersaing dengan produk-produk dari negara lain. Di sisi lain, para konsumen juga mepunyai alternatif pilihan yang beragam yang dapat dipilih sesuai dengan kebutuhan dan kemampuan, dari yang paling murah sampai yang paling mahal. Indonesia sebagai salah satu negara besar yang juga memiliki tingkat integrasi di sektor elektronik dan keunggulan komparatif pada sektor berbasis sumber daya alam, berpeluang besar untuk mengembangkan industri di sektor-sektor tersebut di dalam negeri.

e. Bonus demografi Indonesia sebagai negara dengan jumlah populasi terbesar akan memperoleh keunggulan tersendiri, yang disebut dengan bonus demografi. Perbandingan jumlah penduduk produktif Indonesia dengan Negara-negara ASEAN lain adalah 38:100 yang artinya bahwa setiap 100 penduduk ASEAN, 38 adalah warga Negara Indonesia. Bonus ini diperkirakan masih bisa dinikmati setidaknya sampai dengan 2035, yang diharapkan dengan jumlah penduduk yang produktif akan mampu menopang pertumbuhan ekonomidan peningkatan pendapatan per kapita penduduk Indonesia. ${ }^{30}$

f. Sektor Jasa yang Terbuka.

Sektor-sektor jasa yang telah ditetapkan yaitu pariwisata, kesehatan, penerbangan, dan e-ASEAN dan kemudian akan disusul dengan logistik.

\section{g. Aliran Modal. ${ }^{31}$}

Dari sisi penarikan aliran modal asing, ASEAN sebagai kawasan dikenal sebagai tujuan penanaman modal global.

28 Erman Rajagukguk, “ASEAN-China Free Trade Agreement dan implikasinya bagi Indonesia” dalam "Peranan Hukum di Indonesia: Menjaga Persatuan, Memulihkan Ekonomi dan Memperluas Kesejahteraan Sosial”, Pidato Dies Natalis dan Peringatan Tahun Emas Universitas Indonesia (1950-2000) disampaikan di Depok Universitas Indonesia, 2000) hlm. 11 dalam www.ui.ac.id/lib.ui.ac.id/file diakses tanggal 13 September 2014. Yulianto Syahyu, Hukum Antidumping di Indonesia, (Jakarta: Ghalia Indonesia, 2008) hlm. 30..

Komunitas ASEAN 2015, www.setneg.go.id/index.php/option (diakses 10 September 2014).

1 ASEAN memang menjadi kawasan yang terintegrasi oleh aktor-aktor investasi dari luar, karena arus investasi berteknologi tinggi itu. Kecenderungan ini justru menjadikan ASEAN sebagai suatu mata rantai yang menonjol dalam rangkaian produksi perusahaan multinasional, menuju tercapainya suatu pasar dan basis produksi tunggal yang justru dicanangkan ASEAN untuk diraih lebih atas kekuatan ekonomi negara-negara anggotanya..dalam Martin Khor, Globalisasi Perangkap Negara Negara Selatan, (Yogyakarta: Cindelaras Pustaka Rakyat Cerdas, 2001), hlm. 67. 
Bangsa Indonesia harus segera berbenah diri untuk menyiapkan sumber daya manusia Indonesia yang kompetitif dan berkualitas global. Menuju tahun 2015 yang tinggal sebentar lagi.

\section{Kebijakan Pemerintah Menyongsong Masyarakat Ekonomi ASEAN 2015.}

Pembagian tugas pemerintahan di Indonesia terbagi menjadi dua yaitu pemerintahan Pusat dan Pemerintahan Daerah, dan dalam menjalankan kehidupan bernegara Pemerintah Pusat dan Pemerintah Daerah bersama-sama melakukan pengaturan sebagaimana tugas dan wewenang yang telah diberikan pada masingmasing. Dalam kehidupan bernegara, untuk melaksanakan tugas dan wewenang serta melaksanakan amanat Undang-Undang Pemerintah diberikan kewenangan untuk menetapkan atau mengeluarkan suatu pengaturan baik berupa undang-undang, peraturan hingga kebijakan sesuai dengan porsi kewenangannya. ${ }^{32}$

Dalam rangka pengaturan negara, untuk menghadapi AEC 2015 dibutuhkan kebijakan- kebijakan yang terdiseminasi penuh antara pemerintah pusat, pemerintah daerah, dan masyarakat secara keseluruhan walaupun saat ini masih terdapat ketidak-harmonisan antara pemerintah pusat dan pemerintah daerah serta masyarakat sehingga muncul isu adanya egosektoral kelembagaan dalam upaya persiapan menuju AEC 2015.

Kekompakan antara pemerintah pusat, pemerintah daerah, dan seluruh masyarakat sangat dibutuhkan guna menghadapi AEC 2015 nanti, karena berdampak besar dan akan dirasakan oleh seluruh rakyat Indonesia. Dengan pengetahuan dan kesadaran dari seluruh lapisan masyarakat serta didukung kebijakan yang tepat sasaran akan semakin menguatkan Indonesia menghadapi tantangan besar di depan, dan akan tercipta sinkronisasi antara kebijakan sebagai pengaturan dan sumber daya manusia yang berpengetahuan dan berkesadaran akan persiapan yang harus dilakukan. ${ }^{33}$

Belum lama ini Indonesia memperingati 69 Tahun kemerdekaannya, dan di usia yang 69 tahun sudah seharusnya Indonesia siap mene-

32 Pelaksanaan desentralisasi dan otonomi daerah yang setengah hati dan berada dipersimpangan jalan tentu saja harus dikembalikan ke koridor yang sesungguhnya. Untuk inilah, peran lembaga mediasi seperti Partnership for Governance Reform (PGR) dapat memfasilitasi NGO dan CSO yang dibutuhkan untuk membangun kapasitas masyarakat agar dapat berpartisipasi secara nyata dalam pembangunan. Selain itu, Partnership di samping sebagai mitra pemerintah juga dapat sekaligus memberi tekanan agar agenda desentralisasi dan otonomi daerah tetap berjalan sesuai dengan yang diamanatkan. Intervensi yang bertujuan memperkuat masyarakat sipil dilakukan melalui program yang berkesinambungan dan terukur serta bukan berorientasi pada proyek yang bersifat jangka pendek. Untuk itu, Partnerhip for Governance Reform in Indonesia menjalin kerjasama dengan berbagai pihak yang berkomitmen untuk memperkuat partisipasi untuk mewujudkan terbentuknya masyarakat yang mempromosikan pembaruan tata pemerintahan menuju Indonesia yang adil, demokratis dan sejahtera dalam Rowland B.F. Pasaribu, Dampak Globalisasi dalam kehidupan bermasyarakat, https://rowlandpasaribu. files.wordpress.com (diakses tanggal 13 September 2014).

33 Masalah benturan horizontal antara produk perundang-undangan nasional misalnya saja saat terjadi ekses penerapan UU No. 22 Tahun 1999 tentang Pemerintah Daerah yang semakin meningkatkan akselerasi ekonomi biaya tinggi, karena melahirkan Perda-Perda mengenai berbagai pungutan di daerah yang menambah trade barriers...dengan Undang-Undang Nomor 7 Tahun 1994 tentang Pengesahan Agreement Establishing the World Trade Organization (Perjanjian Pembentukan organisasi Perdagangan Dunia), mewajibkan negara anggotanya melakukan liberalisasi perdagangan, berarti menurunkan trade barriers...dalam Ariawan Gunadi dan Serian Wijatno, Op.Cit. hlm.26. 
rima tantangan AEC 2015 sebagai peluang dan melakukan tindakan-tindakan yang dapat meningkatkan daya saing Indonesia dimata negara lainnya. Untuk meningkatkan peranan Indonesia dalam AEC dibutuhkan langkah kebijakan strategis yang dapat diambil oleh pemerintah. Langkah strategis yang dapat dilaksanakan dalam jangka waktu menengah antara lain: ${ }^{34}$

a. Pemerintah mengoptimalkan penyusunan Roadmap kebijakan nasional yang terpadu dan terkoordinir serta disusun berdasarkan keadaan dan kebutuhan masyarakat melalui kementerian terkait selaku wakil dari negara untuk menghadapi AEC 2015.

b. Pemerintah harus melakukan penyusunan kebijakan untuk edukasi serta sosialisasi terkait ASEAN Community kepada masyarakat secara keseluruhan, sehingga tercipta masyarakat yang berpengetahuan dan berkesadaran.

Arah regulasi seharusnya bukan hanya terkonsentrasi pada sektor perekonomian saja karena dengan terintegrasinya perekonomian dan pemberlakuan pasar tunggal dikawasan regional ASEAN akan membuat batas antar negara memudar, sehingga dibutuhkan kesiapan dari seluruh sektor kehidupan bernegara. ${ }^{35}$ Salah satu tantangannya adalah kualitas sumber daya manusia yang handal dan memiliki kompetensi yang relevan dengan dunia kerja serta sumber daya manusia yang memiliki karakter serta bertanggung jawab sehingga sumber daya manusia Indonesia dapat bersaing dengan sumber daya manusia dari negara lain, bukan justru semakin terpuruk dengan persaingan dengan sumber daya manusia dari negara lain.

Kesiapan menghadapi AEC juga harus dipahami bukan hanya oleh pemerintah selaku perangkat negara melainkan oleh masyarakat secara keseluruhan, karena dengan pemberlakuan AEC pada tahun 2015 kelak masyarakat Indonesia akan merasakan atau terkena dampak sehingga dibutuhkan sosialisasi dan edukasi terkait ASEAN Economic Community kepada masyarakat dan dibutuhkan kebijakan menyikapi hal ini, karena bukan rahasia bahwa negara-negara anggota ASEAN lainnya juga turut mempersiapkan diri menghadapi AEC 2015. ${ }^{36}$

Tagline ASEAN Community yang terdapat dalam Roadmap for ASEAN Community yakni "One Vision, One Identity, One Community" merupakan tantangan bagi seluruh anggota ASEAN, tak terkecuali Indonesia. Satu tujuan, satu identitas, dan satu komunitas merupakan standar yang harus bisa dicapai oleh Indonesia untuk dapat sejajar dan sama dihadapan negara-negara sahabat lainnya. ${ }^{37}$

Ubi societas ibi ius, yang artinya dimana ada masyarakat disitu ada hukum. Pendapat tersebut mendasari pemahaman penulis bahwasanya regulasi pemerintah memiliki peran sebagai pedoman atau arahan pada masyarakat untuk mencapai suatu keadaan yang ingin dicapai, begitu pula halnya dengan kebijakan pemerintah dalam persiapan diri menyongsong AEC 2015. Pemerintah harus segera menetapkan regulasi agar masyarakat dapat turut serta dalam upaya negara mencapai tujuan yang diharapkan. 
Komitmen yang tinggi dari pemerintah Indonesia melalui Presiden RI dalam menyongsong AEC 2015 dapat dicermati dari telah dikeluarkannya serangkaian instrumen kebijakan sebagai acuan para Kementerian dan Lembaga, Pemerintah Daerah serta pemangku kepentingan lainnya untuk mendorong sinergitas dalam meningkatkan kesiapan Indonesia menghadapi AEC 2015. ${ }^{38}$

Suatu kebijakan dapat menjadi arahan atau pedoman untuk mencapai suatu tujuan dan sudah seharusnya pula kebijakan tersebut dapat mengakomodir kebutuhan dan sesuai dengan keadaan masyarakat. Kebijakan sebagai salah satu bentuk persiapan Indonesia untuk menghadapi AEC 2015, juga harus dapat menyentuh seluruh segi kehidupan bernegara secara merata, bukan hanya sosialisasi dan edukasi semata, melainkan juga dapat memberikan ruang bagi sektor-sektor strategis untuk dapat bekerja lebih lagi, misalnya sektor pendidikan. ${ }^{39}$ Kebijakan yang dibuat sepantasnya memberikan terobosan terhadap sektor pendidikan karena melalui sektor pendidikan ini merupakan variabel penentu keberhasilan kreatifitas serta inovasi generasi muda suatu negara dan universitas sebagai salah satu fondasi usaha pembangunan negara sebagai tempat pembelajaran serta penyedia individuindividu yang mempelopori peningkatan sosial dan kejayaan dengan penerapan usaha yang terintegrasi dikalangan multi etnik mengingat kondisi geografis dan sosiologis Indonesia yang terdiri dari berbagai macam budaya dan adat istiadat yang memiliki persepsi dan pemahaman yang berbeda-beda terhadap AEC ini juga.

Upaya-upaya tersebut antara lain dilakukan dengan diterbitkannya Instruksi Presiden No. 5 Tahun 2008 tentang Fokus Program Ekonomi 2008-200940 yang intinya menginstruksikan agar dilakukan upaya sungguh-sungguh dalam meningkatkan pertumbuhan ekonomi Nasional, kelestarian sumber daya alam, peningkatan ketahanan energi dan kualitas lingkungan. Ada juga Inpres Nomor 11 Tahun 2011 tentang Pemenuhan Komitmen Cetak Biru AEC Tahun 2015. ${ }^{41}$

38 Komunitas ASEAN 2015, www.setneg.go.id/index.php/option (diakses 10 September 2014).

39 Zainuddin Djafar,Moon Young Ju, Op.Cit.,hlm. 215.

40 Inpres Nomor 11 Tahun 2011 tentang Pemenuhan Komitmen Cetak Biru AEC Tahun 2015 ini dikeluarkan sebagai upaya pelaksanaan program ekonomi Tahun 2008-2009 Kabinet Indonesia Bersatu yang bersifat prioritas dan memerlukan koordinasi serta sebagai kelanjutan Instruksi Presiden Nomor 6 Tahun 2007 tentang Kebijakan Percepatan Pengembangan Sektor Riil dan Pemberdayaan Usaha Mikro, Kecil dan Menengah dalam www. kemendag.ac.id/news (diakses tanggal 13 September 2014).

41 Fokus Program Ekonomi Tahun 2008-2009, dan Inpres No 11/2011 tentang Pelaksanaan Komitmen Cetak Biru Masyarakat Ekonomi ASEAN. Dan untuk lebih memastikan pelaksanaannya, Unit Kerja Presiden Bidang Pengawasan dan Pengendalian Pembangunan (UKP4) diamanahkan secara khusus untuk melakukan pemantauan dan menyampaikan laporan hasil pemantauannya secara berkala kepada Presiden. Berbagai langkah yang ditempuh Pemerintah Indonesia dalam rangka meningkatkan kesiapan Indonesia untuk memfasilitasi perdagangan barang dan mendorong peningkatan ekspor antara lain melalui peningkatan pengawasan barang beredar khususnya barang-barang impor (pemberdayaan konsumen nasional menjadi konsumen cerdas, peningkatan standardisasi produk melalui penerapan SNI dan labeling, pemenuhan aspek K3L atau Kesehatan, Keamanan, Keselamatan, dan Lingkungan, pengaturan pintu masuk impor, pelaksanaan peraturan dan ketentuan serta prinsip SPS), peningkatan pengawasan penggunaan Surat Keterangan Asal (SKA) barang dari Negara Mitra dagang seperti negara ASEAN, China, Korea, Jepang, India, Australia dan New Zealand, peningkatan pelayanan kepada dunia usaha nasional melalui Indonesia National Single Window (INSW), pengembangan konektifitas nasional termasuk didalanya konektifitas fisik seperti pembangunan infrastruktur di 6 koridor pembangunan ekonomi dalam kerangka MP3EI dan lain sebagainya diakses dari www.kemendag.go.id/news (diakses tanggal 9 September 2014). 
Bentuk konkrit komitmen Pemerintah ini juga akan ditopang secara kelembagaan dengan akan dibentuknya Komite Nasional yang terdiri dari perwakilan pemerintah pusat dan daerah, Menteri, Gubernur, dunia usaha, pengamat dan masyarakat untuk mempersiapkan seluruh elemen bangsa dalam menyambut Komunitas Ekonomi ASEAN 2015.

Rekomendasi strategis untuk menyiapkan Indonesia menghadapi AEC 2015 dalam upaya meningkatkan kualitas sumber daya manusia perlu mendapat dukungan dari berbagai pemangku kepentingan melalui upaya komprehensif ekstensifikasi dan intensifikasi Balai Latihan Kerja (BLK) untuk menutupi masih rendahnya daya saing tenaga kerja, Lembaga Standarisasi Profesi di Indonesia yang mencapai 78 perlu lebih dioptimalkan melalui adopsi standarisasi Internasional (ASEAN) yang berlaku. ${ }^{42}$ Gerakan kewirausahaan Nasional juga perlu ditingkatkan gaungnya dan diikuti dengan program intensif khususnya bagi gerakan kewirausahaan di sektor pendidikan (Perguruan Tinggi-Akademisi), Usaha Kecil Menengah (UKM) dan kelompok industri lainnya untuk memperbaiki standar, kualitas, dan desain produk, serta kreatifitas dan inovasi dalam mengembangkan produk.

Upaya-upaya yang dilakukan pemerintah dalam hal ini Kementerian Tenaga Kerja dan Transmigrasi belum maksimal mengingat belum ada antisipasi terhadap pekerja-pekerja asing diwilayah ASEAN yang akan bebas masuk dan bekerja di Indonesia untuk tingkat ASEAN sendiripun hal ini masih dalam pembahasan dalam forum-forum Senior Official Meeting belum sampai pada tahap Konferensi Tingkat Tinggi ASEAN atau pertemuan para pemimpinpemimpin Negara-negara anggota ASEAN. ${ }^{43}$ Tampaknya bukan hanya pemerintah Indonesia yang terus mempersiapkan diri menghadapi AEC 2015 ini ASEAN sendiripun sebagai wadah regional Negara-negara di Asia Tenggara terus mempersiapkan semua perangkat hukum maupun non hukum untuk menghadapi AEC ini. ${ }^{44}$ Sehingga apa yang akan dihadapi pada pemberlakuan AEC pada Desember 2015 nanti masih menjadi pertanyaan besar bagi ASEAN secara luas dan Indonesia secara sempit namun memang tak bisa dihindari arus globalisasi terus meminta Negara-negara untuk membuka diri satu sama lain semakin menipisnya batas antar Negara semakin tak terbendung karena kemajuan teknologi dan kebutuhan masyarakat Internasional semakin mengglobal maka mau tak mau siap atau tidak siap seluruh elemen bangsa harus bersiap dan mempersiapkan diri sedini mungkin sambil belajar dari pengalaman komunitas Eropa yang telah terlebih dahulu sukses di Eropa, ASEAN khususnya Indonesia bisa belajar dari pengalaman Uni Eropa dalam memberlakukan European Union dengan segala perangkat hukum dan non hukum untuk mempermudah kerjasama diantara Negaranegara anggotanya..$^{45}$

42 Maman Setiawan, "Strategi Pengembangan UKM Berdasarkan Sektor Ekonomi dalam Rangka Peningkatan Penyerapan Tenaga Kerja di Indonesia" Makalah disampaikan pada Seminar Internasional Simposium Kebudayaan Indonesia-Malaysia ke X yang diselenggarakan di Universitas Padjadjaran, Bandung, 29-31 Mei 2007.

ASEAN Economic Community Blueprint,http://www.aseansec.org/21083.pdf, (diakses 8 September 2014).

44 R. Dwisaputra, Kerjasama Perdagangan Regional dalam Kerjasama Perdagangan Internasional: Peluang dan tantangan bagi Indonesia, (Jakarta, PT. Elex Media Komputindo, 2007), hlm. 28.

45 C.P.F.Luhulima, Op.Cit., hlm. 41. 
Di samping itu pemerintah Indonesia harus optimis diantara banyaknya pesimisme disana sini terkait kesiapan Indonesia menghadapi AEC 2015 bentuk optimisme ini diwujudkan dalam berbagai upaya baik secara substantif maupun moril dengan mengajak seluruh elemen bangsa untuk bersiap, membuka diri, belajar dan bersaing dengan Negara-negara ASEAN lainnya tanpa berupaya mengesampingkan angkaangka statistik tentang ketidak-siapan Indonesia dalam menyongsong AEC 2015 namun keputusan telah diambil dan bangsa ini sudah menyatakan diri siap membuka diri dan bersaing sehingga angka-angka yang menunjukkan kualitas bangsa Indonesia secara kompetensi ${ }^{46}$ harus dijadikan acuan untuk mengembangkan diri dan membuka diri terhadap kritikan dengan menjadikan kritikan itu sebagai motivasi meningkatkan kualitas individu-individu bangsa Indonesia untuk menjadi sebuah bangsa pemenang yang telah teruji secara kompetensi melalui kompetisi terbuka oleh sebab itu pemerintah Indonesia pun harus semakin meningkatkan kinerjanya melalui transparansi, akuntabilitas, kemudahan dan kecepatan layanan, online system, ${ }^{47}$ persempit birokrasi, penghapusan pungli-pungli, koordinasi yang integral baik secara horizontal maupun vertikal dan yang terpenting kesiapan mental ketika bangsa Indonesia bukannya hanya harus hidup berdampingan dengan bangsa-bangsa anggota ASEAN lainnya yang memiliki perbedaan etnik, ras, agama dan bahasa ${ }^{48}$ lalu harus berkompetisi dengan pekerja-pekerja asing ini juga tanpa perbedaan perlakuan mengingat secara demografi populasi Indonesia besar, luas wilayah Indonesia sangat besar dan kekayaan alam Indonesia melimpah, hal-hal ini menjadi daya tarik tersendiri bagi pekerja-pekerja asing untuk masuk ke Indonesia tak terkecuali negaranegara anggota ASEAN. ${ }^{49}$

Secara garis besar pemerintah telah menyiapkan langkah-langkah yang dianggap penting dan strategis dalam menghadapi Masyarakat Ekonomi ASEAN 2015 yang sudah didepan mata, ada 12 langkah strategis yang menjadi sektor prioritas yang dianggap mampu bersaing dan dijadikan tumpuan perekonomian Indonesia menghadapi MEA 2015. Semua langkah-langkah strategis ini bermuara pada peningkatan daya saing yang mau tidak mau harus ditingkatkan terus bila Indonesia mau menjawab tantangan MEA 2015 ini mengingat besarnya peluang Indonesia menjadi "leading country" di ASEAN. ${ }^{50}$

Peningkatan daya saing ini juga telah disadari sepenuhnya oleh pemerintah Indonesia salah satunya di sektor perikanan.

46 Sjamsul, Arifin, dkk, Masyarakat Ekonomi ASEAN 2015: Memperkuat Sinergi ASEAN di Tengah Kompetisi Global, (Jakarta: PT. Elex Media Komputindo, 2008), hlm. 78.

47 Berry, A, E. Rodriguez and H. Sandee, Op.Cit. :17.

48 Komunitas ASEAN 2015, www.setneg.go.id/index.php/option (diakses 10 September 2014).

49 Kendala investasi di Indonesia yang umum terjadi misalnya seperti: pengurusan izin yang terlalu bertele-tele, perilaku negatif birokrasi, pembatasan bidang usaha, kelemahan infrastruktur yang mendukung investasi, serta belum terciptanyakepastian hukum dan penegakan hukum, disamping juga fasilitas perpajakan. ASEAN Free Trade Area yang menjadi sarana bagi peningkatan investasi di Indonesia memberikan dorongan agar di Indonesia dilakukan pembaharauan hukum investasi, atau bilamana dimungkinkan dilakukan perubahan-perubahan seperlunya yang daapt mengakomodir kepentingan investasi di Indonesia dalam Zainuddin Djafar,Moon Young Ju, Anissa Farha Mariana, Op.Cit., hlm. 49.

50 Raisa Samantha Sudana, "Peranan Kebijakan Pemerintah Indonesia dalam Persiapan Menyongsong ASEAN Economic Community 2015" e-journal dalam https://www.conftool.com/sudana (diakses 13 September 2014). 
Kementerian Kelautan dan Perikanan telah mempersiapkan Rancangan Instruksi Presiden (Inpres) Peningkatan Daya Saing Nasional Sektor Kelautan dan Perikanan yang disusun dibawah koordinasi Kemenko Perekonomian yang saat ini dalam proses penandatanganan Presiden. ${ }^{51}$ Diharapkan melalui Inpres ini tantangan seperti kurangnya dukungan infrastruktur, transportasi atau logistik, perangkat hukum, penyediaan energi, pengembangan industri terpadu, serta terbatasnya jumlah sumber daya manusia yang kompeten untuk mendukung produktivitas nasional dapat teratasi. Memang tujuan yang ingin dicapai MEA ASEAN dalam Visi ASEAN 2020 merupakan visi jangka panjang yang ingin mengembangkan kawasan regional di Asia Tenggara mampu bersaing dengan kawasan lain di belahan dunia maka Indonesia sebagai salah satu Negara pendiri ASEAN dan merupakan Negara dengan sejarah yang sudah lama di ASEAN sejogianya mampu memimpin Negaranegara anggota ASEAN lainnya bersaing dengan kawasan regional di dunia.

Di Kementerian Perdagangan sendiri upaya untuk menjawab tantangan globalisasi bukan hanya MEA $2015^{52}$ secara sempit telah mempersiapkan diri demi upaya pencapaian perlindungan konsumen dan pengamanan pasar dalam negeri dengan membentuk Direktorat Jenderal Standardisasi dan Perlindungan Konsumen melalui Peraturan Menteri Perdagangan No. 31 Tahun 2010 yang telah disempurnakan dengan Peraturan Menteri Perdagangan No. 57 Tahun 2012 tentang Organisasi dan Tata Kerja Kementerian
Perdagangan dengan misi meningkatkan daya saing ekspor, meningkatkan pengawasan dan perlindungan konsumen, serta berperan sebagai pengelola kebijakan maupun pelaksanaan atas program pengembangan sekaligus pengamanan perdagangan dalam negeri. Dengan demikian dapat dikatakan Kementerian-kementerian dibawah koordinasi Kemenko Perekonomian dipaksa terlebih dahulu siap menghadapi MEA 2015 karena dari tiga pilar visi ASEAN 2020 yang dikedepankan terlebih dahulu pilar MEA ini dan sudah didepan mata sehingga pemerintah berupaya mengamankan sektor perekonomian terlebih dahulu agar tidak gagap dan kaget menghadapi perubahan dan semoga perubahan ini nantinya akan membawa Indonesia bersama-sama dengan ASEAN menjadi Negara yang sejahtera dan mampu bersaing dengan komunitas Internasional, bukan berarti sendi kehidupan lainnya boleh santai dalam menghadapi MEA ini tetapi justru lebih terpacu untuk mempersiapkan diri karena setelah MEA maka dua pilar visi ASEAN 2020 akan dimajukan juga oleh karena itu sangat dibutuhkan koordinasi antar lembaga-lembaga Negara karena untuk mencapai suatu tujuan koordinasi dan kerjasama sangatlah penting bukan hanya untuk melindungi kepentingan Nasional saja tetapi untuk mencapai tujuan bernegara yang diwujudkan dalam konstitusi Undang-Undang Dasar Negara Kesatuan Republik Indonesia yaitu mewujudkan masyarakat yang adil dan makmur.

Kebijakan yang telah dikeluarkan atau ditetapkan belum terlalu berdampak pada kehidupan bermasyarakat, selain itu masih 
ditemukan kendala kurang kompaknya pemerintah di tingkat pusat dan daerah dalam mengantisipasi hal ini, padahal AEC merupakan momentum yang akan menentukan masa depan Indonesia dan ASEAN secara keseluruhan.

Kebijakan yang telah ada dan yang akan ada akan terlihat dampak atau keberlakuannya ketika kebijakan tersebut berisi pengaturan yang bersinggungan langsung dengan kehidupan masyarakat. Hingga saat ini kebijakan-kebijakan yang telah ditetapkan oleh pemerintah terkait persiapan menghadapi AEC 2015 belum dirasakan berdampak pada masyarakat Indonesia secara keseluruhan, artinya dampak kebijakan tersebut masih berdampak pada minoritas masyarakat Indonesia. Hal tersebut sangat disayangkan mengingat kesiapan seluruh lapisan masyarakat sangat dibutuhkan dalam rangka persiapan menghadapi AEC 2015.

\section{Penutup}

Indonesia sebagai salah satu negara pertama yang memberlakukan hukum persaingan telah berperansecaraaktifmenjadicentreofexcellence dalam pengembangan hukum persaingan ini di ASEAN melalui pembagian pengalaman (sharing experience). Dalam perspektif kompetisi, konsekuensi dari terbukanya pasar akibat kebebasan peredaran barang dan jasa (free flow of goods and services) adalah munculnya persaingan baru, pasar bersangkutan baru dan potensi ketersentuhan pelaku usaha Indonesia dengan hukum persaingan negara-negara tetangga seperti Malaysia dan Singapura. Oleh karena itu Komisi Pengawas Persaingan Usaha yaitu Komisi yang bertugas mengawasi Persaingan Usaha dengan Komisi VI DPR RI memiliki komitmen untuk mengamandemen Undang-Undang Nomor 5 Tahun 1999 tentang Anti Monopoli dan Persaingan Usaha Tidak sehat supaya KPPU lebih "bertaring" dalam menjalankan tugas menangani perkara terkait persaingan usaha sehat.

Secara garis besar peluang Indonesia menyongsong MEA antara lain mendapatkan pangsa pasar potensial dunia, sebagai negara tujuan investasi, peluang sebagai negara pengekspor, adanya liberalisasi perdagangan barang ASEAN, bonus demografi yang besar, sektor jasa yang terbuka, dan aliran modal yang lebih lancar dan kontinyu. Sedangkan tantangan yang akan dihadapi antara lain laju peningkatan ekspor dan impor yang lebih kompetitif, peningkatan laju inflasi, dampak negatif arus modal yang lebih luas, adanya kesamaan produk ekspor unggulan sehingga harus lebih kreatif mencari dan mengelola produk unggulan dan tingkat perkembangan ekonomi yang masih beragam yang harus dicarikan solusinya.

Berbagai upaya pemerintah dalam menghadapi MEA antara lain dengan penerbitan Instruksi Presiden No. 5 Tahun 2008 tentang Fokus Program Ekonomi 2008-2009 yang intinya menginstruksikan agar dilakukan upaya sungguh-sungguh dalam meningkatkan pertumbuhan ekonomi Nasional, kelestarian sumber daya alam, peningkatan ketahanan energi dan kualitas lingkungan. Lalu Inpres Nomor 11 Tahun 2011 tentang Pemenuhan Komitmen Cetak Biru AEC Tahun 2015. Bentuk konkrit komitmen Pemerintah ini juga akan ditopang secara kelembagaan dengan akan dibentuknya Komite Nasional yang terdiri dari perwakilan pemerintah pusat dan daerah, Menteri, Gubernur, dunia usaha, pengamat dan masyarakat untuk mempersiapkan seluruh elemen bangsa dalam menyambut Komunitas Ekonomi ASEAN 2015. Peningkatan daya saing ini juga telah disadari sepenuhnya oleh pemerintah salah satunya di sektor perikanan. 
Kementerian Kelautan dan Perikanan telah mempersiapkan Rancangan Instruksi Presiden (Inpres) Peningkatan Daya Saing Nasional Sektor Kelautan dan Perikanan yang disusun dibawah koordinasi Kemenko Perekonomian yang saat ini dalam proses penandatanganan Presiden. Di Kementerian Perdagangan sendiri upaya untuk menjawab tantangan globalisasi bukan hanya MEA 2015 secara sempit dengan membentuk Direktorat Jenderal Standardisasi dan Perlindungan Konsumen melalui Peraturan Menteri Perdagangan No. 31 Tahun 2010 yang telah disempurnakan dengan Peraturan Menteri Perdagangan No. 57 Tahun 2012 tentang Organisasi dan Tata Kerja Kementerian Perdagangan dengan misi meningkatkan daya saing ekspor, meningkatkan pengawasan dan perlindungan konsumen, serta berperan sebagai pengelola kebijakan maupun pelaksanaan atas program pengembangan sekaligus pengamanan perdagangan dalam negeri.

Hal yang perlu mendapat prioritas untuk segera direalisasikan yaitu agar pemerintah dan DPR segera mengamandemen UndangUndang Nomor 5 Tahun 1999 tentang Anti Monopoli dan Persaingan Usaha Tidak sehat untuk memberikan amunisi bagi KPPU dalam menjalankan tugas menangani perkara terkait persaingan usaha sehat dengan melibatkan berbagai stakeholder.

\section{DAFTAR PUSTAKA}

\section{Buku}

Amiruddin dan Zainal Asikin, Pengantar Metode Penelitian Hukum (Jakarta: Rajawali Pers, 2012). Ariawan, Perjanjian Perdagangan Bebas dalam era Liberalisasi Perdagangan: Studi mengenai ASEAN-China Free Trade Agreement (ACFTA) yang diikuti oleh Indonesia, (Jakarta, Disertasi Fakultas Hukum Universitas Indonesia, 2012).

Arifin, Sjamsul, Dian Ediana Rae, Charles P.R. Joseph, Kerjasama Perdagangan Internasional: Peluang dan tantangan bagi Indonesia, (Jakarta: Elex Media Komputindo, 2007).

Arifin, Sjamsul, dkk, Masyarakat Ekonomi ASEAN 2015: Memperkuat Sinergi ASEAN di Tengah Kompetisi Global, (Jakarta: PT. Elex Media Komputindo, 2008).

Bhagwati, J, The World Trading System at Risk, (Hertfordshire: Harvester Wheatsheaf, 1991).

Brotosusilo, Agus, Globalisasi Ekonomi dan Perdagangan Internasional: Studi tentang Kesiapan Hukum Indonesia melindungi Produksi Dalam Negeri melalui Undang-Undang Anti Dumping dan Safeguard (Disertasi Universitas Indonesia, 2006).

Departemen Perdagangan Republik Indonesia, Menuju Asean Economic Community 2015 (Jakarta:Dir.Jen.Kerjasama Perdagangan Internasional Departemen Perdagangan,2010).

Dwisaputra, R, Kerjasama Perdagangan Regional dalam Kerjasama Perdagangan Internasional: Peluang dan tantangan bagi Indonesia, (Jakarta, PT. Elex Media Komputindo, 2007).

Gunadi, Ariawan dan Serian Wijatno, Perdagangan Bebas dalam Perspektif Hukum Perdagangan Internasional (Jakarta: Grasindo, 2014).

Hartono, C.F.G Sunaryati, Penelitian Hukum di Indonesia Pada Akhir Abad ke-20 (Bandung: Alumni, 1994).

Hassan, Mohamed Jahwar, The Resurgence of China and India, major Power Rivalry and The Response of ASEAN, dalam Hadi Soesastro dan Clara Joewono (eds.), The Inklusif Regionalist (Jakarta: Centre For Strategic And International Studies Indonesia, 2007).

Halwani, Hendra, Ekonomi Internasional dan Globalisasi Ekonomi, (Jakarta: Ghalia Indonesia, 2002).

Hendra Halwani, M.A dan Prijono Tjiptoherijanto, Perdagangan Internasional: Pendekatan Ekonomi Mikro dan Makro, (Jakarta: Ghalia Indonesia, 1993).

Khor, Martin, Globalisasi Perangkap Negara Negara Selatan, (Yogyakarta: Cindelaras Pustaka Rakyat Cerdas, 2001).

Luhulima, C.P.F, Dinamika Asia Tenggara menuju 2015 (Jakarta: Pustaka Pelajar bekerjasama dengan Pusat Penelitian Politik (P2P) LIPI, 2010).

M. Kuncoro, Analisis Spasial dan Regional:Studi Aglomerasi dan Kluster Industri Indonesia, (Yogyakarta: UPP AMP YKPN, 2002).

Mantra, Dodi, Hegemoni dan diskursus Neoliberalisme: Menelusuri Langkah Indonesia 
Menuju Masyarakat Ekonomi ASEAN 2015 (Bekasi: Mantra Press, 2011).

Plummer G, Michael, Creating an ASEAN Economic Community: Lesson from the $E U$ and Reflections on the Roadmap" dalam Denis Hew, Roadmap to an ASEAN Economic Community (Singapore: Institute of Southeast Asian Studies, 2005).

Pusat Penelitian Politik Lembaga IImu Pengetahuan Indonesia, Hubungan Indonesia-Cina dalam Dinamika Politik, Pertahanan-Keamanan, dan Ekonomi di Asia Tenggara/Lidya Christin Sinaga (ed.) (Jakarta: LIPI Press, 2013).

Soekanto,Soerjono dan Sri Mamuji, Penelitian Hukum Normatif, Suatu Tinjauan Singkat (Jakarta: CV Rajawali, 1990).

Syahyu, Yulianto, Hukum Antidumping di Indonesia, (Jakarta: Ghalia Indonesia, 2008).

Tinjauan Kompas, Menatap Indonesia 2014 Tantangan, Prospek Politik dan Ekonomi Indonesia (Jakarta: PT. Kompas Media Nusantara, 2014).

Zainuddin Djafar,Moon Young Ju,Anissa Farha Mariana, Peran Strategis Indonesia dalam Pembentukan ASEAN dan Dinamikanya, Kajian Kebijakan Polugri RI, UKM Regional, Implikasi Liberalisasi Perdagangan, Realitas Piagam ASEAN dan Esensi Kompetisi Regional (Jakarta: Penerbit Universitas Indonesia (UI Press), 2012).

\section{Makalah / Artikel / Prosiding / Hasil Penelitian}

Rodriguez, Berry, A, E. and H. Sandee,"Small and Medium Enterprise Dynamics in Indonesia", (Bulletin of Indonesian Economic Studies, Vol. 37 No. 2, 2001).

Messi, Nawir, "Kompetisi menuju pasar bebas ASEAN," (Majalah Kompetisi edisi 42 2013).

Mitsuhiro, Hayashi, "Development of SMEs in the Indonesian Economy", Journal of Asian Economics (2002).

Setiawan, Maman, "Strategi Pengembangan UKM Berdasarkan Sektor Ekonomi dalam Rangka Peningkatan Penyerapan Tenaga Kerja di Indonesia" Makalah disampaikan pada Seminar Internasional Simposium Kebudayaan Indonesia-Malaysia ke $X$ yang diselenggarakan di Universitas Padjadjaran, Bandung, 29-31 Mei 2007.

\section{Internet}

ASEAN Vision 2020, dalam www.asean.org/news/ item/asean-vision-2020 (diakses 8 September 2014).

ASEAN Concord II/Bali Concord II, http://www. aseansec.org/15159.htm (diakses 8 September 2014).

ASEAN Economic Community Blueprint, http://www. aseansec.org/21083.pdf, (diakses 8 September 2014).

Badan Pusat Statistik Republik Indonesia,"Indikator Sosial Budaya 2003, 2006, 2009, dan 2012" Badan Pusat Statistik Republik Indonesia www. bps.go.id/tab_sub/view.php/tabel (diakses 9 September 2014).

Biro Riset Ekonomi Direktorat Riset Ekonomi dan Kebijakan Moneter Bank Indonesia, Outlook Ekonomi Indonesia 2008-2012 Integrasi Ekonomi ASEAN dan Prospek Perekonomian Nasional, http://www.bi.go.id/id/publikasi/kebijakanmoneter/outlookekonomi/Documents/1f4a5d 59ed7841bd95ebde10dd6525890EI_0108.zip (diakses 13 September 2014)

Bris Witjaksono, Djatmiko, "Bertahan dan Menang menyongsong Masyarakat Ekonomi ASEAN (MEA) 2015 (makalah disampaikan dalam pembukaan Seminar setengah hari oleh Kementerian Perdagangan, di Smesco Jakarta, 11 Desember 2013 dalam www.kemendag.go.id/ id/news/2013/12/12 (diakses 8 September 2014).

Komunitas ASEAN 2015,www.setneg.go.id/index. php/option (diakses 10 September 2014).

Rajagukguk, Erman, ASEAN-China Free Trade Agreement dan implikasinya bagi Indonesia dalam "Peranan Hukum di Indonesia: Menjaga Persatuan, Memulihkan Ekonomi dan Memperluas Kesejahteraan Sosial", Pidato Dies Natalis dan Peringatan Tahun Emas Universitas Indonesia (1950-2000) disampaikan di Depok Universitas Indonesia, 2000) www.ui.ac.id/ lib.ui.ac.id/file (diakses tanggal 13 September 2014).

Rowland B.F. Pasaribu, Dampak Globalisasi dalam kehidupan bermasyarakat, https:// rowlandpasaribu.files.wordpress.com (diakses tanggal 13 September 2014).

Raisa Samantha Sudana, "Peranan Kebijakan Pemerintah Indonesia dalam Persiapan Menyongsong ASEAN Economic Community 
2015" e-journal dalam https://www.conftool. com/sudana (diakses 13 September 2014).

Sholeh "Persiapan Indonesia dalam menghadapi Asean Economic Community 2015", ejournal. hi.fisip-unpad.org (diakses 13 September 2014).

\section{Peraturan-Peraturan}

Undang-Undang Nomor 5 Tahun 1999 tentang Larangan Praktek Monopoli dan Persaingan Usaha Tidak Sehat (Lembaran Negara Republik Indonesia Tahun 1999 Nomor 33, Tambahan Lembaran Negara Republik Indonesia Nomor 3817).

Peraturan Presiden Nomor 9 Tahun 2005 tentang Kedudukan, Tugas, Fungsi, Tata Kerja, dan Susunan Organisasi Kementerian Negara Koperasi dan UKM yang telah diubah dengan Peraturan Presiden Nomor 62 Tahun 2005 tentang Perubahan atas Peraturan Presiden Nomor 9 Tahun 2005 tentang Kedudukan, Tugas, Fungsi, Tata Kerja, dan Susunan Organisasi Kementerian Negara Koperasi dan UKM.
Keputusan Presiden Republik Indonesia Nomor 228/M Tahun 2001 tentang Pembentukan kabinet Gotong Royong.

Keputusan Presiden Republik Indonesia Nomor 101 Tahun 2001 tentang Kedudukan, Tugas, Fungsi, Kewenangan, Susunan Organisasi dan Tata Kerja Lembaga Pemerintah Non Departemen.

Keputusan Presiden Republik Indonesia Nomor 103 Tahun 2001 tentang Kedudukan, Tugas, Fungsi, Kewenangan, Susunan Organisasi, dan Tata Kerja Lembaga Pemerintah Non Departemen.

Keputusan Presiden Republik Indonesia Nomor 108 Tahun 2001 tentang Unit Organisasi dan Tugas Eselon I Menteri Negara.

Instruksi Presiden Nomor 5 Tahun 2008 tentang Fokus Program Ekonomi 2008-2009.

Inpres Nomor 11 Tahun 2011 tentang Pemenuhan Komitmen Cetak Biru AEC Tahun 2015.

Peraturan Menteri Perdagangan No. 31 Tahun 2010 yang telah disempurnakan dengan Peraturan Menteri Perdagangan No. 57 Tahun 2012 tentang Organisasi dan Tata Kerja Kementerian Perdagangan. 